\title{
PEMANFAATAN CITRA RESOLUSI TINGGI UNTUK IDENTIFIKASI PERUBAHAN OBYEK BANGUNAN (Studi Kasus Updating Rencana Detil Tata Ruang Kota Unit Pengembangan Rungkut Surabaya)
}

\author{
Dewi Nur Indah Sari, Teguh Hariyanto, Akbar Kurniawan \\ Jurusan Teknik Geomatika FTSP ITS-Sukolilo, Surabaya 60111 \\ Email: teguh_hr@geodesy.its.ac.id
}

\begin{abstract}
Abstrak
Perkembangan teknologi penginderaan jauh terutama citra WorldView-2 memudahkan dalam mengkaji perencanaan tata ruang kota dan monitoring penggunaan lahan, contohnya perubahan obyek bangunan. Kota Surabaya yang terletak antara $07^{\circ} 12^{\prime}-07^{\circ} 21^{\prime}$ Lintang Selatan dan $112^{\circ} 36^{\prime}-112^{\circ} 54^{\prime}$ Bujur Timur yang aktivitas kotanya sangat bervariasi dengan jumlah penduduk lebih dari tiga milyar (Hasyim, Hariyanto, dkk. 2011). Kegiatan pembangunan fisik dan prasarana perkotaan di Surabaya tentunya menimbulkan konsekuensi terhadap perubahan obyek bangunan. Untuk mengatasi permasalahan ini salah satu langkah yang diambil oleh pemerintah dijelaskan dalam tema pengembangan UP Rungkut yaitu sinergitas pengembangan kawasan permukiman perbatasan kota sebagai penyangga kegiatan industri dan pendidikan dengan pendekatan sustainable development.
\end{abstract}

Dalam penelitian ini, identifikasi perubahan obyek bangunan pada tahun 2002 sampai dengan 2012 dilakukan dengan memanfaatkan data peta garis digital tahun 2002 dan citra WorldView-2 dengan menggunakan metode klasifikasi terselia berdasarkan maximum likelihood (kemiripan maksimum) untuk mengidentifikasi perubahan obyek bangunan pada UP Rungkut pada Tahun 2002 sampai dengan 2012.

Hasil penelitian ini menunjukkan bahwa luas perubahan obyek bangunan di UP Rungkut pada tahun 2002-2012 seluas $220.333 \mathrm{Ha}$. Untuk hasil kesesuaian perubahan obyek bangunan dengan RDTRK UP Rungkut tahun 2010 yaitu bangunan yang sesuai $209.025 \mathrm{Ha}$, tidak sesuai $11.308 \mathrm{Ha}$ dan yang belum dimanfaatkan seluas $1096.171 \mathrm{Ha}$. Hal ini menandakan perlu adanya langkah-langkah dari semua pihak terkait untuk mengaplikasikan rencana tata ruang agar pembangunan kota bisa berjalan secara serasi dan terpadu antara masing-masing komponennya dalam mencapai tujuan-tujuan yang telah ditetapkan dalam pola dasar pembangunan daerah.

Kata kunci : WorldView-2, Obyek Bangunan, RDTRK, Surabaya

\section{PENDAHULUAN}

Penggunaan penginderaan jauh dapat mencakup suatu areal yang luas dalam waktu bersamaan. Menurut Puntodewo dkk (2003), penginderaan jauh dapat digunakan untuk penelitian lingkungan hidup mengenai interaksi antara sistem alam dan bumi. Penginderaan jauh dapat digunakan untuk menganalisis spasial secara cepat, efektif, efisien dan dapat mencakup wilayah yang lebih luas bila dibandingkan dengan pengukuran langsung yang membutuhkan biaya serta tenaga yang lebih banyak.

Perkembangan teknologi penginderaan jauh terutama citra WorldView-2 memudahkan dalam mengkaji perencanaan tata ruang kota dan monitoring penggunaan lahan, contohnya perubahan obyek bangunan. Sejak kemunculannya yang pertama kali di Indonesia, WorldView-2 langsung mendapat respon positif dari berbagai institusi pemerintah. Didorong pula oleh pemberian otonomi yang lebih luas kepada Pemda, maka WorldView-2 telah dimanfaatkan untuk menyusun peta rencana detail tata ruang paling up to date. WorldView-2 memiliki keunggulan mampu menyajikan data dengan resolusi spasial tinggi, yaitu $0.46 \mathrm{~m}-0.5 \mathrm{~m}$ untuk citra pankromatik dan $1.84 \mathrm{~m}$ untuk citra multispektral (www.worldview2.digitalglobe.com) Sehingga perkembangan wilayah kota tersebut dapat di kendalikan sesuai dengan orientasi perencanaan pembangunan kota agar tidak menimbulkan permasalahan-permasalahan baru.

Kota Surabaya yang terletak antara $07^{\circ} 12^{\prime}-07^{\circ} 21^{\prime}$ Lintang Selatan dan $112^{\circ} 36^{\prime}-112^{\circ} 54^{\prime}$ Bujur Timur yang aktivitas kotanya sangat bervariasi dengan jumlah penduduk lebih dari tiga milyar (Hasyim, 
Hariyanto, dkk. 2011). Hal ini terjadi karena kemajuan Kota Surabaya terutama dalam bidang ekonomi menjadi daya tarik tersendiri bagi masyarakat yang ada di sekitarnya. Akibatnya, jumlah penduduk yang tinggal di wilayah Kota Surabaya semakin banyak. Kondisi ini berpengaruh terhadap meningkatnya kebutuhan penduduk akan hunian, perkantoran, sarana dan prasarana transportasi, serta fasilitas publik lainnya. Konsekuensinya, pembangunan fisik kota pun semakin meningkat, guna memenuhi kebutuhan penduduk tersebut. Pembangunan fisik dan prasarana perkotaan dapat berupa pembangunan permukiman sebagai tempat tinggal, pembangunan pabrik dan perkantoran sebagai tempat bekerja, pembangunan jaringan jalan sebagai penghubung dan jenis pembangunan lainnya. Kegiatan pembangunan fisik dan prasarana perkotaan di Surabaya tentunya menimbulkan konsekuensi terhadap perubahan obyek bangunan. Dengan terjadinya perubahan obyek bangunan, maka perlu adanya sebuah studi identifikasi perubahan luasan obyek bangunan dengan menggunakan data citra WorldView-2 serta melengkapi data perubahan obyek bangunan berupa basis data format Sistem Informasi Geografis untuk updating Rencana Detail Tata Ruang Kota Surabaya.

\section{PERUMUSAN MASALAH}

Dari latar belakang di atas, maka permasalahan yang timbul adalah :

a. Bagaimana cara identifikasi perubahan obyek bangunan dengan memanfaatkan data citra satelit WorldView-2.

b. Bagaimana evaluasi tentang basis data perubahan obyek bangunan format Sistem Informasi Geografis sebagai penunjang updating Rencana Detail Tata Ruang Kota Surabaya.

\section{BATASAN MASALAH}

Batasan masalah dari penelitian tugas akhir ini adalah:

a. Daerah penelitian mencakup Unit Pengembangan Rungkut (Kecamatan Rungkut, Kecamatan Gununganyar, Kecamatan Tenggilis Mejoyo) Kota Surabaya. b. Data citra yang digunakan adalah citra satelit WorldView-2 tahun 2012.

c. Obyek yang dididentifikasi adalah bangunan perumahan, perdagangan jasa, fasilitas umum dan bangunan industri.

d. Hasil dari penelitian ini adalah Peta Kesesuaian Perubahan Obyek Bangunan UP Rungkut dengan RDTRK tahun 2010 dan basis data perubahan obyek bangunan format Sistem Informasi Geografis sebagai penunjang updating Rencana Detail Tata Ruang Kota Surabaya.

\section{TUJUAN}

Tujuan dari penelitian ini adalah :

a. Identifikasi perubahan luasan obyek bangunan untuk updating Rencana Detil Tata Ruang Kota Surabaya.

b. Pembuatan Peta Kesesuaian Perubahan Obyek Bangunan UP Rungkut dengan RDTRK tahun 2010.

c. Melengkapi data perubahan obyek bangunan berupa basis data format Sistem Informasi Geografis sebagai penunjang kegiatan updating Rencana Detil Tata Ruang Kota Surabaya.

\section{METODOLOGI PENELITIAN}

\section{Lokasi Penelitian}

Lokasi penelitian tugas akhir ini dilakukan di Kota Surabaya. Secara geografis Surabaya terletak pada $07^{\circ} 12^{\prime}-07^{\circ} 21^{\prime}$ Lintang Selatan dan $112^{\circ} 36^{\prime}$ $112^{\circ} 54^{\prime}$ Bujur Timur. Luas dari Kota Surabaya adalah $374,36 \mathrm{~km}^{2}$. 


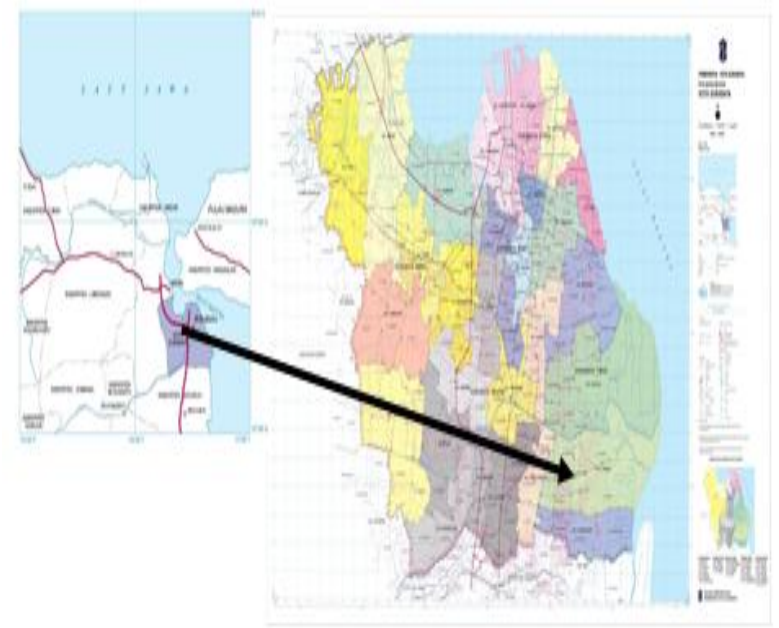

Gambar 1. Lokasi Penelitian (www.bakosurtanal.go.id)

Data dan Peralatan

Data

Data yang dibutuhkan yaitu dalam penelitian Tugas Akhir ini antara lain:

Data Spasial :

1. Peta Garis Digital Surabaya skala 1:5000 tahun 2002

2. Data citra satelit WorldView-2 tahun 2012.

Data Non Spasial :

1. Data pokok pembangunan Kota Surabaya berupa data fisik terbitan Kantor Pertanahan Kota Surabaya.

2. Peta RDTRK (Peta Rencana Detil Tata Ruang Kota) Tahun 2010.

Peralatan

Peralatan yang digunakan dalam penelitian ini adalah

Perangkat Keras (Hardware)

1. GPS Navigasi Garmin eTrx H High Sensitivity Perangkat Lunak (Software)

1. ENVI (Environment for Visualizing Images) 4.6.1 untuk seluruh proses pengolahan citra.

2. Autodesk Land Desktop 2004

3. ArcGIS 9.3

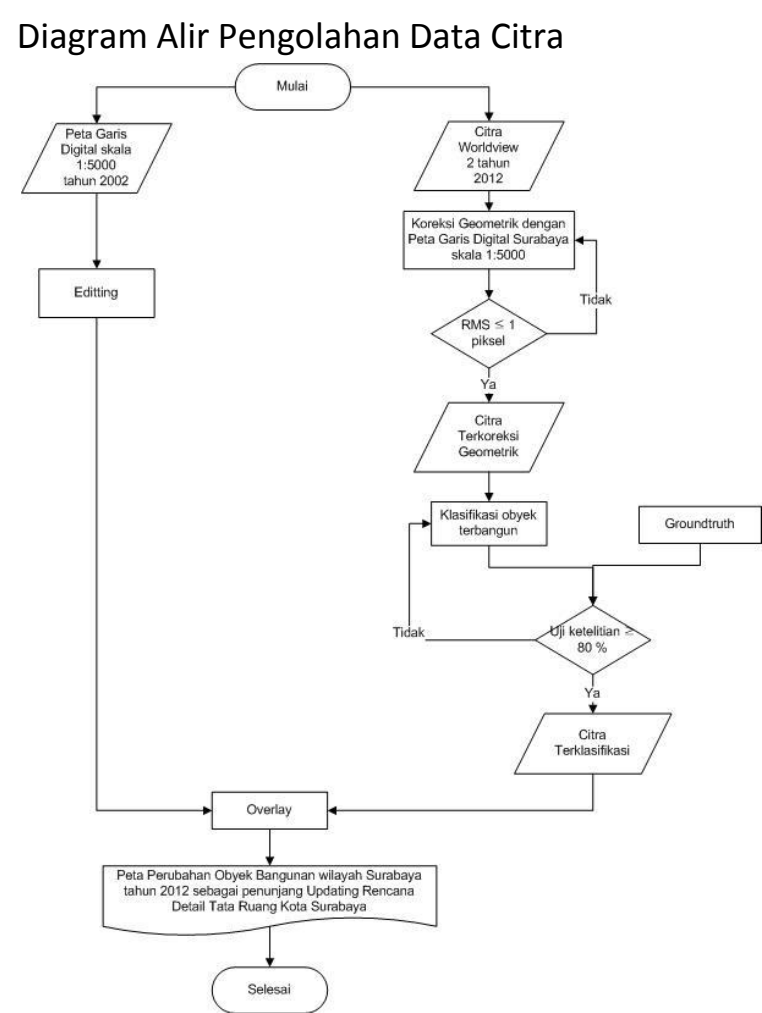

Gambar 2. Diagram Alir Tahap Pengolahan Data Citra

Berikut ini adalah penjelasan diagram alir tahap pengolahan data :

1. Data

Data yang digunakan dalam penelitian Tugas Akhir ini adalah Citra Satelit WorldView-2 dan Peta Garis Digital Kota Surabaya skala 1:5000 tahun 2002.

2. Koreksi Geometrik

Koreksi geometrik perlu dilakukan untuk mendapatkan sistem koordinat dan sistem proyeksi yang sama antara citra dengan peta acuan. Pada koreksi ini digunakan peta garis digital sebagai referensi. Penentuan lokasi Ground Control Point (GCP) dilakukan dengan mengidentifikasi batas-batas alam yang tergambar jelas pada peta. pada penelitian ini digunakan titik kontrol sebanyak 12 buah. Model transformasi yang digunakan adalah polinomial derajat satu karena dianggap daerah penelitian mempunyai kondisi yang relatif datar (tidak berbukit). Ketelitian dari penempatan titik kontrol dan akurasi koreksi geometrik dapat diketahui dari nilai RMS. Apabila nilai RMS mendekati nol maka titik tersebut dianggap benar (Purwadhi 2001), tetapi apabila nilainya $\geq 1$ piksel maka titik tersebut harus dikoreksi kembali. Setelah 
masing-masing titik mempunyai nilai RMS $\leq 1$ piksel maka citra tersebut telah menjadi citra yang terkoreksi secara geometrik.

3. Klasifikasi

Klasifikasi perubahan obyek bangunan yang digunakan adalah klasifikasi supervised berdasarkan fungsi normal Gauss atau yang biasa disebut kemiripan maksimum (Maximum Likelihood) yaitu dengan menggambar training area untuk masingmasing tipe obyek bangunan yang harus dipisahkan pada klasifikasi dan menggunakan karakteristik seperti rona, bentuk, dan pola masing-masing area untuk mengklasifikasi objek yang termasuk obyek bangunan. Metode ini digunakan karena hasil klasifikasi pada metode ini lebih peka terhadap pola tanggapan spektral.

4. Uji Ketelitian Klasifikasi

Ground truth dalam penelitian ini bertujuan untuk validasi data hasil klasifikasi dengan kondisi lapangan. Uji ketelitian merupakan tahapan penting untuk menentukan tingkat akurasi metode klasifikasi yang dihasilkan. Uji ketelitian klasifikasi dalam penelitian ini yaitu dengan membuat matriks dari perhitungan setiap kesalahan (confusion matrix) pada setiap bentuk obyek bangunan hasil klasifikasi dari citra satelit yang digunakan dimana dilakukan pembuatan matriks dari perhitungan setiap kesalahan pada setiap bentuk obyek bangunan dari hasil interpretasi citra penginderaan jauh. Untuk syarat uji ketelitian yaitu harus lebih dari sama dengan 80\%. (Purwadhi 2001)

5. Overlay Citra hasil klasifikasi dengan peta Garis digital

Overlay dilakukan menggunakan software ArcGIS 9.3 untuk dilakukan interpretasi dan identifikasi perubahan terhadap obyek bangunan.

6. Identifikasi Perubahan Obyek Bangunan.

Proses identifikasi dilakukan pada Citra WorldView-2 yang telah terkoreksi geometrik dan terklasifikasi lalu ditampalkan dengan peta garis digital skala 1:5000 tahun 2002, kemudian dilakukan digitasi perubahan obyek bangunan berdasarkan jenis perubahan obyek bangunan.

7. Hasil.
Hasil identifikasi dan digitasi perubahan obyek bangunan, kemudian disajikan dalam bentuk peta perubahan obyek bangunan dan Sistem Informasi Geografis sebagai penunjang kegiatan updating Rencana Detail Tata Ruang Kota Surabaya.

Diagram Alir Pembuatan Basis Data Format SIG

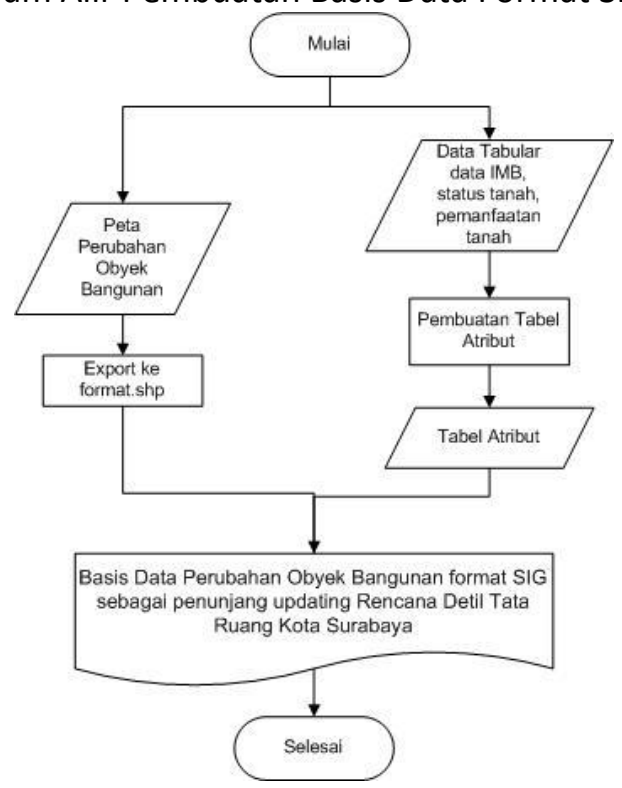

Gambar 3. Diagram Alir Pembuatan Basis Data Format SIG

\section{HASIL DAN PEMBAHASAN}

\section{Hasil}

Citra

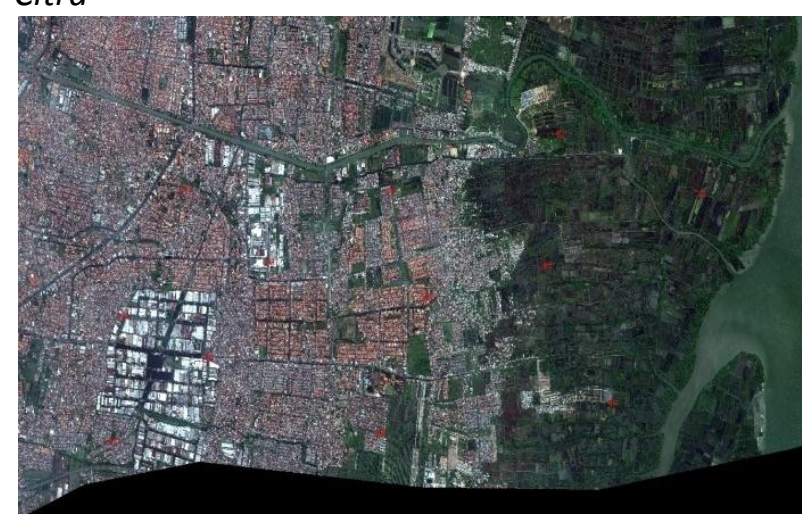

Gambar 4. Hasil Citra Terkoreksi Tahun 2012

Perhitungan SoF dan Koreksi Geometrik

Berikut ini merupakan desain jaring untuk perhitungan Sof citra WorldView-2 tahun 2012 : 


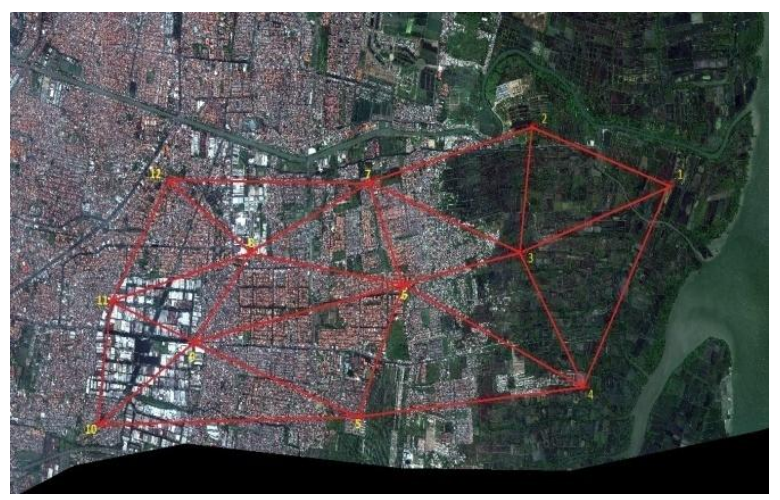

Gambar 5. Desain Jaring Citra WorldView-2 Tahun 2012

$\begin{array}{ll}\text { Jumlah Titik } & : 12 \text { buah } \\ \text { Jumlah Baseline } & : 25 \text { buah } \\ \text { N ukuran } & : 22 \text { buah } \\ \text { N parameter } & : 50 \text { buah } \\ \text { U } & : 50-22=28 \text { buah } \\ \text { Besar SoF } & =\operatorname{trace}\left\{([\mathrm{A}] \times[\mathrm{A}] \mathrm{T})^{\prime}\right\} \\ \mathrm{U} & =0.3425\end{array}$

Memenuhi nilai yang diberikan yaitu mendekati nol,sehingga desain jarring SoF dianggap kuat. (Abidin 2007).

Koreksi geometrik Citra WorldView-2 tahun 2012 dilakukan dengan menggunakan peta garis digital tahun 2002 skala 1:5000. Jumlah Ground Control Point (GCP) yang digunakan sebanyak 12 titik yang tersebar di seluruh daerah penelitian.

Pada penelitian ini total nilai RMS error kurang dari 1 piksel atau 0,52 sehingga koreksi dianggap sudah memenuhi toleransi yang diberikan.

\section{Klasifikasi Obyek Terbangun}

Proses klasifikasi dilakukan dengan metode klasifkasi terselia maksimum likelihood dengan training sample setiap proses klasifikasi jumlahnya bertambah. Jumlah kelas yang digunakan sejumlah 5 kelas tutupan lahan. Kelas yang dipilih yaitu bangunan, vegetasi, badan air, tambak dan tanah kosong. Namun dalam penelitian ini yang akan dianalisa adalah hasil klasifikasi dari obyek bangunan saja.
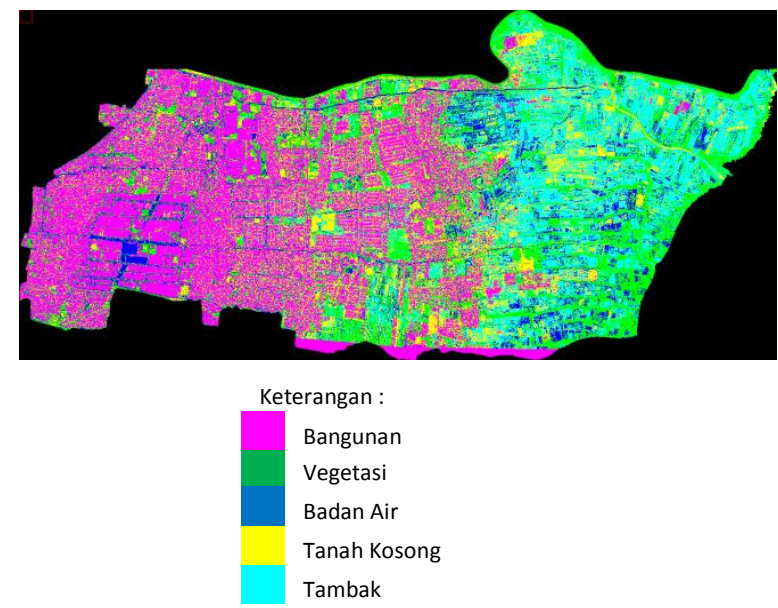

\section{Gambar 6. Citra Hasil Klasifikasi Dengan Training Sample Obyek Bangunan Sebanyak 1000}

\section{Uji Ketelitian Klasifikasi}

Uji ketelitian dilakukan untuk mengetahui ketelitian hasil klasifikasi, Metode yang digunakan untuk perhitungan adalah confusion matrix. Sebelum dilakukan uji ketelitian diperlukan ground truth atau survey lapangan untuk kelas obyek bangunan. Berikut contoh titik-titik hasil survey lapangan:

Tabel 1. Titik-Titik Hasil Survei Lapangan

\begin{tabular}{llll}
\hline No & Easting $(\mathrm{m})$ & Northing $(\mathrm{m})$ & Kelas \\
\hline 1 & 227885 & 688952 & pabrik \\
2 & 227922 & 688962 & pabrik \\
3 & 227951 & 688948 & pabrik \\
4 & 227624 & 690075 & permukiman \\
5 & 227638 & 690067 & permukiman \\
6 & 227645 & 690063 & permukiman \\
7 & 229096 & 690986 & perumahan \\
8 & 229106 & 691001 & perumahan \\
9 & 229087 & 691010 & perumahan \\
10 & 229113 & 691018 & perumahan \\
\hline
\end{tabular}

Perhitungan uji ketelitian dengan metode confusion matrix ini dilakukan dengan dua cara macam cara yaitu dengan perangkat lunak ENVI 4.6.1 dan perhitungan manual. Untuk hasil perhitungan dengan perangkat lunak dan manual berdasarkan hasil uji lapangan yang lebih lengkap terlampir.

Berikut merupakan hasil confusion matrix dari masing-masing klasifikasi dengan software dan manual : 
Tabel 2. Hasil Confusion Matrix

\begin{tabular}{llll}
\hline \multirow{2}{*}{ No } & \multirow{2}{*}{ Klasifikasi } & \multicolumn{2}{c}{ Hasil Confusion Matrix (\%) } \\
& Software ENVI & Manual \\
\hline 1 & $\begin{array}{l}\text { Training } \\
\text { sample 22 }\end{array}$ & 72,89 & 73,33 \\
2 & $\begin{array}{l}\text { Training } \\
\text { sample } 400\end{array}$ & 74,17 & 75,67 \\
3 & $\begin{array}{l}\text { Training } \\
\text { sample } 500\end{array}$ & 84,63 & 83,09 \\
4 & $\begin{array}{l}\text { Tarining } \\
\text { sample 1000 }\end{array}$ & 85,78 & 85,71 \\
\hline
\end{tabular}

Selain itu uji ketelitian juga dilakukan dengan membandingkan hasil luasan obyek bangunan setiap proses klasifikasi dengan luasan dari peta garis digital 2012 yang di olah sebelumnya. Berikut merupakan hasil perbandingan luasan klasifikasi dengan peta garis :

Tabel 3. Presentasi Luas Klasifikasi dengan Peta Garis 2012

\begin{tabular}{|c|c|c|c|c|c|}
\hline No & Keterangan & $\begin{array}{l}\text { Luasan } \\
\text { Hasil } \\
\text { Klasifikasi } \\
\text { Obyek } \\
\text { Bangunan } \\
\text { (Ha) }\end{array}$ & $\begin{array}{l}\text { Luasan } \\
\text { Bangunan } \\
\text { Peta } \\
\text { Garis } \\
2012(\mathrm{Ha})\end{array}$ & $\begin{array}{l}\text { Selisih } \\
(\mathrm{Ha})\end{array}$ & $\begin{array}{l}\text { Selisih } \\
(\%)\end{array}$ \\
\hline 1 & $\begin{array}{l}\text { Training } \\
\text { sample } 22\end{array}$ & 913.044 & & 102.235 & 10.06 \\
\hline 2 & $\begin{array}{l}\text { Training } \\
\text { sample } 400\end{array}$ & 894.130 & & 121.149 & 11.93 \\
\hline 3 & $\begin{array}{l}\text { Training } \\
\text { sample } 500\end{array}$ & 1238.383 & 1015.279 & 223.104 & 21.97 \\
\hline 4 & $\begin{array}{l}\text { Training } \\
\text { sample } \\
1000\end{array}$ & 1209.216 & & 193.937 & 19.10 \\
\hline
\end{tabular}

Dapat disimpulkan dari analisa di atas bahwa untuk melakukan uji ketelitian pada hasil klasifikasi, hasil yang lebih tepat yaitu dilakukan dengan menggunakan perhitungan confusion matrix baik dengan cara software ataupun hitungan manual.

\section{Analisa}

\section{Identifikasi Obyek Bangunan pada Citra Resolusi Tinggi}

Untuk mendeteksi perubahan suatu obyek dan menghitung perbedaannya secara temporal pada penelitian ini dilakukan dengan menggunakan klasifikasi citra berbasis piksel yaitu metode postclassification. Metode post-classification merupakan metode yang umum digunakan dengan cara mengklasifikasi masing-masing citra satelit temporal tersebut untuk mengidentifikasi adanya perubahan tutupan dan penggunaan laha $^{[5]}$. Namun dalam penggunaannya metode ini masih mempunyai banyak kekurangan antara lain tidak bisa menghasilkan hasil klasifikasi dengan kesesuaian secara spasial yang tinggi juga tidak dapat mengidentifikasikan bentuk obyek secara tepat terutama pada citra resolusi spasial tinggi, seperti WorldvView-2 yang digunakan pada penelitian ini.

Hal ini sesuai dengan hasil klasifikasi citra yang telah dilakukan dalam penelitian ini. Untuk meminimalisir kesalahan yang ditimbulkan dapat dilakukan dengan beberapa cara :

a. Proses klasifikasi yang berulang-ulang dan setiap proses klasifikasi training sample yang digunakan harus semakin banyak. Hal ini dilakukan untuk membandingkan hasil klasifikasi sehingga didaptkan hasil yang bisa dianggap benar.

b. Dikarenakan citra satelit resolusi tinggi mempunyai kenampakan obyek yang sangat bervariasi sehingga dibutuhkan kelas training sample yang semakin banyak. Hal ini untuk mengatasi berbedaan warna yang sangat beragam padasatu obyek.

c. Untuk proses uji klasifikasi dibutuhkan peta acuan yang dianggap benar dan sesuai secara temporal. Peta acuan ini digunakan untuk uji ketelitian dari segi spasial dari hasil klasifikasi yang telah dianggap benar.

Tabel 4. Luas Perubahan Obyek Bangunan tahun 2002-2012 UP Rungkut

\begin{tabular}{|c|c|c|c|}
\hline No & $\begin{array}{l}\text { Keterangan Luas } \\
\text { Bangunan }\end{array}$ & Obyek & Luas (Ha) \\
\hline 1 & Luas 2002 & & 643.414 \\
\hline 2 & $\begin{array}{l}\text { Luas } 2012 \\
\text { klasifikasi) }\end{array}$ & (hasil & 954.162 \\
\hline 3 & $\begin{array}{l}\text { Luas Perubahan } \\
2012\end{array}$ & 2002- & 310.748 \\
\hline
\end{tabular}

Pada tabel di atas disebutkan bahwa hasil luasan obyek bangunan pada tahun 2002 yaitu seluas $643.414 \mathrm{Ha}$. Sedangkan luasan obyek bangunan pada tahun 2012 yaitu 954.162 Ha. Sehingga didapatkan luasan perubahan obyek bangunan dari tahun 2002 sampai dengan tahun 2012 yaitu $310.748 \mathrm{Ha}$. Namun hasil luasan ini masih belum dapat digunakan, dikarenakan bentuk obyek bangunan pada tahun 2012 masih dalam bentuk blok yang menyebabkan hasil klasifikasi bangunan 
masih ada yang masuk pada obyek lain seperti jalan, batas rumah, dan taman. Sehingga perlu dilakukan proses selanjutnya, yaitu digitasi, untuk mendapatkan obyek bangunan dalam bentuk persil. Proses digitasi ini dilakukan pada hasil perubahan obyek bangunan yang dioverlay dengan Citra Satelit WorldView-2 tahun 2012 untuk mengetahui obyek bangunan dalam bentuk persil. Setelah itu dihitung pula jumlah luasan obyek bangunan dalam bentuk persil yaitu seluas $220.333 \mathrm{Ha}$.

\section{Evaluasi Kesesuaian Peruntukkan Lahan untuk Obyek Bangunan dengan RDTRK}

Pada penelitian ini data peruntukkan lahan yang dibutuhkan hanya obyek bangunan saja. Jadi pada tabel data RDTRK di atas data yang akan diambil hanya data perumahan, fasilitas umum, perdagangan dan jasa, serta industry dan pergudangan.

Tabel 5. Luas Kesesuaian Perubahan Obyek Bangunan berdasarkan RDTRK UP Rungkut

\begin{tabular}{lll}
\hline & Luas Perubahan & Obyek \\
No & Bangunan & Luas (Ha) \\
\hline 1 & Tahun 2002-2012 & 220.333 \\
2 & Sesuai & 209.025 \\
3 & Tidak Sesuai & 11.308 \\
\hline
\end{tabular}

Dari tabel 5 didapatkan bahwa berdasarkan luasan perubahan obyek bangunan pada UP Rungkut yang seluas $220.333 \mathrm{Ha}$, setelah dianalisa dengan Peta RDTRK UP Rungkut tahun 2010, dihasilkan 209.025 Ha yang sesuai dan $11.308 \mathrm{Ha}$ yang tidak sesuai.

Tabel 6. Luas Lahan yang Belum Dimanfaatkan sebagai Obyek Bangunan

\begin{tabular}{lll}
\hline No & Luas Obyek Bangunan & Luas $(\mathrm{Ha})$ \\
\hline 1 & RDTRK 2010 & 2111.450 \\
2 & Tahun 2012 & 1015.279 \\
3 & Belum Dimanfaatkan & 1096.171 \\
\hline
\end{tabular}

Tingkat kesesuaian pengguanaan lahan terhadap RDTRK secara umum masih tidak menunjukkan kesesuaian antara apa yang direncanakan dalam RDTRK tersebut dengan kondisi penggunaan lahan pada saat ini. Hal ini dapat dilihat pada perbedaan luasan perubahan obyek bangunan tahun 20022012 yang sesuai dengan luas $209.025 \mathrm{Ha}$ dan tidak sesuai dengan luas $11.308 \mathrm{Ha}$, perbedaan 54 luasan lahan yang belum dimanfaatkan sebagai obyek bangunan dengan luas 1096.171 Ha dari rencana obyek bangunan pada RDTRK UP Rungkut dengan luas $2111.45 \mathrm{Ha}$.

Melihat kesesuaian pada perubahan luasan obyek bangunan dari tahun 2002 sampai tahun 2012, walaupun perubahannya sesuai dengan tema RDTRK UP Rungkut yaitu mengembangkan kawasan permukiman perbatasan (tepi), masih terdapat lahan yang belum dimanfaatkan seperti yang telah direncanakan dalam RDTRK dan masih ada penggunaan lahan yang tidak sesuai dengan RDTRK UP 1 Rungkut. Hal ini menandakan perlu adanya langkah-langkah dari semua pihak terkait untuk mengaplikasikan rencana tata ruang agar pembangunan kota bisa berjalan secara serasi dan terpadu antara msing-masing komponennya dalam mencapai tujuan-tujuan yang telah ditetapkan dalam pola dasar pembangunan daerah. Khususnya lebih mengoptimalkan lagi pembangunan obyek pemukiman karena dalam kurun waktu 10 tahun pembangunan pemukiman belum berkembang seperti yang direncanakan dalam RDTRK.

\section{Evaluasi Hasil Basis Data format SIG}

Setelah dilakukan proses identifikasi maka didapatkan hasil penambahan obyek bangunan pada seluruh UP Rungkut yang meliputi tiga kecamatan, yaitu Kecamatan Rungkut, Gununganyar dan Tenggilis Mejoyo. Kemudian diambil sampel basis data pada satu kelurahan saja yaitu Kelurahan Penjaringan Sari. Pada penelitian ini basis data yang akan dibuat yaitu basis data dengan format SIG. Basis data yang akan dibuat meliputi informasi Nomer Surat Ukur (SU) Bangunan, No Hak Bangunan, dan Jenis Hak Bangunan.

Data spasial yang akan digunakan yaitu Peta Perubahan Obyek Bangunan Kelurahan Penjaringan Sari tahun 2002-2012. Peta Penjaringan Sari yang akan digunakan yaitu sebagai berikut : 


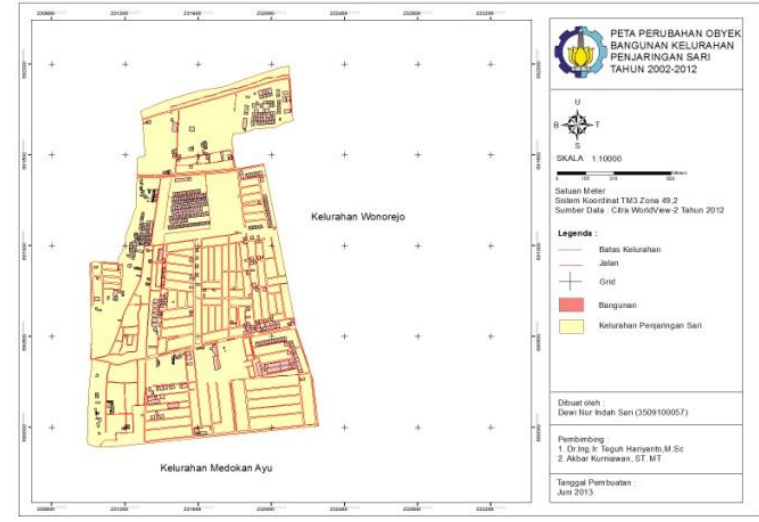

Gambar 7. Peta Perubahan Obyek Bangunan Kelurahan Penjaringan Sari Tahun 2002-2012

Sedangkan data atribut yang telah dimasukkan pada setiap obyek bangunan pada Peta Penjaringan Sari di atas yaitu sebagai berikut :

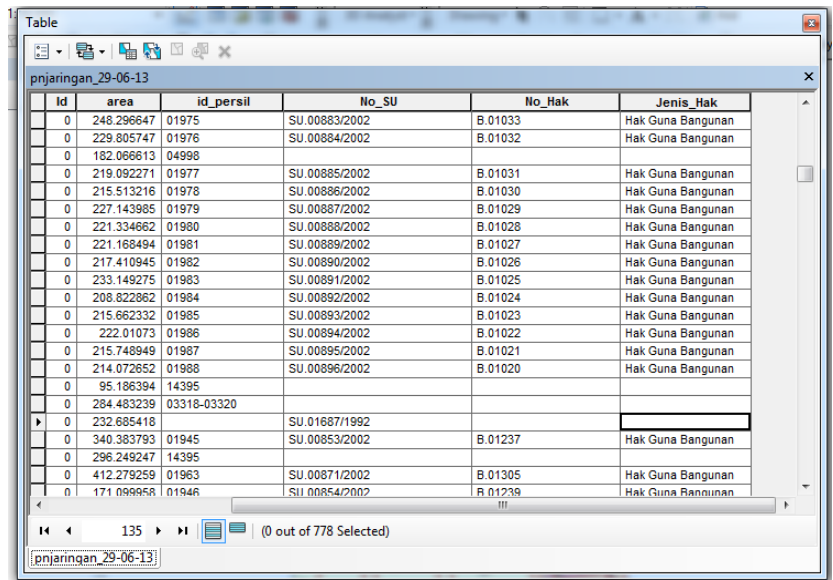

Gambar 9. Basis Data format SIG

Selanjutnya dilakukan evaluasi pada hasil basis data yang telah dibuat. Proses evaluasi dilakukan untuk mengetahui jumlah obyek bangunan yang sudah mempunyai data yang lengkap dan jumlah obyek bangunan yang belum mempunyai data yang lengkap yaitu meliputi data id_persil, No_SU, No_Hak dan Jenis_Hak.

Dari hasil evaluasi diapatkan 778 obyek bangunan yang merupakan jumlah penambahan obyek bangunan pada Kelurahan Penjaringan Sari tahun 2002-2012. Dari hasil tersebut terdapat:

a. 329 obyek bangunan yang telah memiliki data lengkap yaitu data id_persil, No_SU, No_Hak dan Jenis_Hak.

b. 124 obyek bangunan yang belum mempunyai data id_persil, No_SU, No_Hak dan Jenis_Hak. c. 453 obyek bangunan yang belum memiliki data lengkap, mislnya hanya memiliki data Jenis_Hak saja.

\section{KESIMPULAN DAN SARAN}

\section{Kesimpulan}

Berdasarkan hasil penelitian tentang identifikasi perubahan obyek bangunan dengan menggunakan Citra Satelit WorldView-2 dengan studi kasus UP 1 Rungkut kota Surabaya, maka didapatkan kesimpulan sebagai berikut :

a. Hasil perhitungan luas perubahan obyek bangunan pada tahun 2002 sampai dengan tahun 2012 untuk UP Rungkut yaitu seluas 310.748 Ha. Dan luasan perubahan obyek bangunan per persil yang didapatkan yaitu seluas $220.333 \mathrm{Ha}$.

b. Hasil kesesuaian perubahan obyek bangunan beradasarkan RDTRK UP Rungkut yaitu luasan perubahan obyek bangunan tahun 2002-2012 yang sesuai dengan luas $209.025 \mathrm{Ha}$ dan tidak sesuai dengan luas $11.308 \mathrm{Ha}$, perbedaan luasan lahan yang belum dimanfaatkan sebagai obyek bangunan dengan luas 1096.171 Ha dari rencana obyek bangunan pada RDTRK UP Rungkut dengan luas 2111.45 $\mathrm{Ha}$.

c. Hasil evaluasi basis data format SIG yaitu terdapat 778 obyek bangunan pada Kelurahan Penjaringan Sari dimana 329 obyek bangunan memiliki data lengkap, 124 obyek bangunan belum memiliki data dan 453 obyek bangunan yang datanya belum lengkap.

\section{Saran}

Saran yang dapat disampaikan dari penelitian tersebut adalah sebagai berikut :

a. Berdasarkan hasil identifikasi obyek bangunan pada citra resolusi tinggi yang telah dilakukan disarankan bahwa untuk meminimalisir kesalahan dapat dilakukan dengan beberapa cara proses klasifikasi yang berulang-ulang, memperbanyak kelas training sample dan menggunakan peta acuan yang benar.

b. Lebih mengoptimalkan lagi pembangunan khususnya lahan permukiman karena dalam kurun waktu 10 tahun pembangunan permukiman bellum berkembang seperti yang direncanakan. Hal ini bertujuan untuk 
mewujudkan rencana pengembangan UP Rungkut menjadi kawasan permukiman perbatasan (tepi).

c. Perlu adanya tindakan tegas oleh setiap pihak yang terkait dalam hal ini Dinas Tata Kota, BAPPEKO dan BPN jika terjadi penyimpangan penggunaan lahan sesuai yang ada dalam RDTRK.

\section{DAFTAR PUSTAKA}

Hasyim, A.W., Hariyanto, T., Taufik, M., Sulistyarso, H., May 2011. "Urband Land Use Change Analysis Using Temporal Multispectral Imagery and Image Difference". International Journal of Academic Research Vol. 3, No. 3, I Part.

Puntodewo A, Dewi S, dan Tarigan J. 2003. Sistem Informasi Geografis Untuk Pengelolaan Sumber Daya Alam. Bogor Barat : Center for International Forestry Research.

<URL:http://worldview2.digitalglobe.com> . Dikunjungi pada tanggal 15 September 2012, jam 16.00 .

Purwadhi, S.H. 2001. Interpretasi Citra Digital. Jakarta: Grasindo.

Tsai, Yu Hsin, Stow, Douglas, Weeks, John. 2011. Comparison of Object-Based Image Analysis Approaches to Mapping New Buildings in Accra, Ghana Using MultiTemporal QuickBird Satellite Imagery. Department of Geography, San Diego State University, 5500 Campanile Dr., San Diego, CA 92182. 


\section{LAMPIRAN}

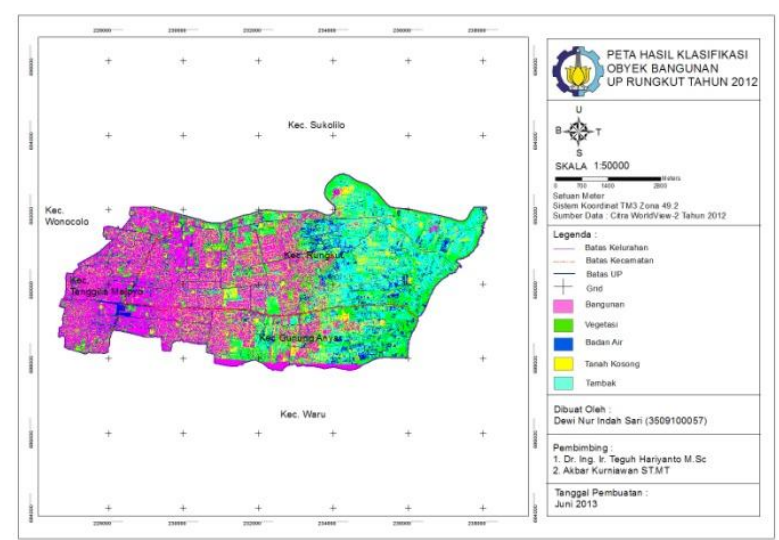

Gambar 10. Peta Hasil Klasifikasi Obyek Bangunan UP Rungkut Tahun 2012

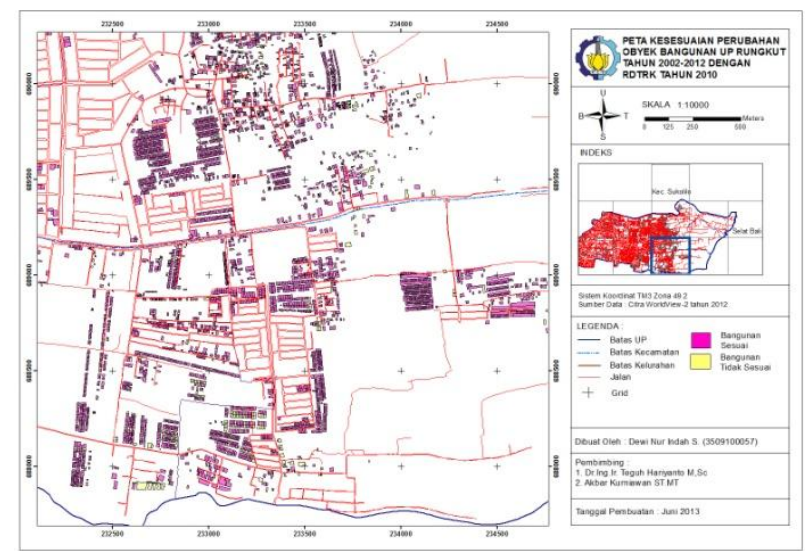

Gambar 11.Peta Kesesuaian Perubahan Obyek Bangunan UP Rungkut Tahun 2002-2012 dengan RDTRK Tahun 2010

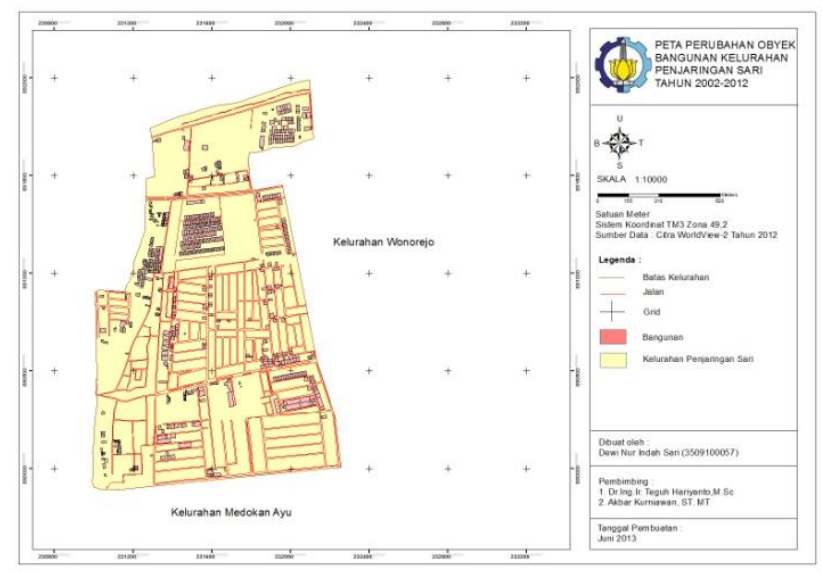

Gambar 12. Peta Perubahan Obyek Bangunan

Kelurahan Penjaringan Sari tahun 2002-2012 